Website: http://jsci.utq.edu.iq

\title{
Effects of Aluminum chloride on some hormones levele and reproductive organs of male rats (Rattus norvegicus)
}

\author{
Rasha Salih Nuhair \\ Department of Biology. College of sciences. University of Thi-Qar . Thi- Qar/ Iraq \\ Email: salihrasha06@Gmail.com
}

\section{Summary :}

This study was conducted at the Veterinary Medicine, University of Basrah to investigate the effect of Aluminium Chloride on some hormones and histological changes in the laboratory Male Rats (Rattus norvegicus). Rats sexually mature (16 weeks age) and 250 \pm 50 gm weighing, were used, they were divided into Four groups, each one consisted of 8 male rats in , Three groups were dosed Orally with 25,50 and $100 \mathrm{mg} / \mathrm{kg} \mathrm{B}$.W. aluminium in the form of $\mathrm{HgCl}_{2}$ for 21 days consecutive. An equivalent volume of distal water was administered to the fourth group which was set as the control group. Levels of the LH, FSH and Testosterone hormones were evaluated . in addition to histo - pathological changes of the Epididymis and testis. Results of this study indecate a significant decrease $(\mathrm{P} \leq 0.05)$ of FSH, LH and Testosterone hormones concentrations in treated groups compared with control groupe. The histopathological changes in Testis and epididymis were obvious in all treated groups comparison with control.

Key words: aluminum chloride - hormones - reproductive organs

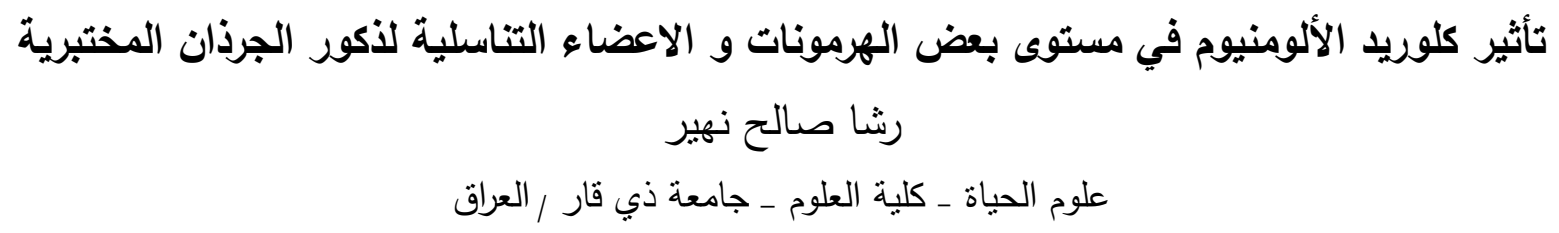

الخلاصة :

اجريت الدراسة لمعرفة ناثير كلوريد الالمنيوم في مستوى بعض الهرمونات الجنسية والاعضاء التتاسلية الذكرية في الجرذان المختبرية. استخدم في التجربة

الحالية (32) ذكرا بالغا، قسمت عشوائيا الى اربعة مجاميع منساوية بواقع 8 لكل مجموعة اعطيت المجموعة الاولى الماء المقطر لمدة 21 يوم واعتبرت كمجموعة سيطرة ،جرعت المجموعة الاولى والثانية والثالثة ب(25و 50و 100 ملغم/كغم ) على التوالي بكلوريد الالمنيوم لمدة 21 يوما. اظهرت النتائج وجود انخفاض معنويا (PS0.05) في مستوى نركيز الهرمون اللوتيني، الهرمون المحفز لنمو الجريب وهرمون التيسيتيرون في الحيونات المعاملة مقارنة

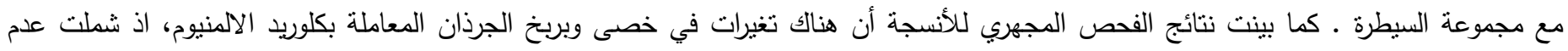
وجود النطف والارومات النطفية في خصى وبربخ الذكور المعاملة مقارنة مع مجموعة السيطرة .

\section{Introduction}

Aluminium ( $\mathrm{Al})$ is the third most abundant element in the earth's crust and makes up approximately $8 \%$ of its rocks and minerals. It occurs naturally in soil, water, air, and many foods (Verstraeten, et al., 2008). Aluminium has the potential to be neurotoxic in human and animals. Aluminum poisoning could affect on learning, memory and it is an important candidate for Alzheimer disease (Koenig and Jope, 1987). It presents in many manufactured foods and medicines and also added to drinking water for purification purposes (Newairy, 2009). The main sources of aluminium are corn, yellow cheese, salt, herbs, tea leaves, cosmetics, from aluminium ware and containers (Naraynan , 2014). Aluminium is widely used in antacid drugs, as well as, in food additives and tooth paste (Abbasali, 2005). Aluminum and its compounds have a variety of applications in different branches of industry, particularly in the aircraft, motor car and electrical industries. Al compounds 
are used in manufacturing glass, ceramic products, rubber, wood preservatives or pharmaceuticals. Welders and workers employed in electrolytic heat and aluminum casting, or in the production of abrasive materials are among those who are mostly exposed to Al dusts and fumes(Sinczuk-walczak et al., 2003). Al is known as a neuro- toxin that can cause certain diseases such as Alzheimer disease, dialysis dementia, Parkinsonism, and amyotrop-ic lateral sclerosis (Wurtman, 1985). In addition to its neurotoxicity, $\mathrm{Al}$ affects other body structures like the skeletal system, 6 brain tissue, and blood cells (Mestaghanmi et al., 2002). Animal studies in rats and case reports have implicated the use of oral aluminum-containing antacids during pregnancy as a possible cause for abnormal fetal neurologic development (Shuchang et al.,2008). Aluminium chloride was implicated to have negative effects on behavioural endpoints of wistar rats( i.e. alters behaviour), have negative effects on anxiety-related behaviour of wistar rats as it increased the rate of anxiety in aluminium treated rats, had neurodegenerative effects on the histology of cerebral cortex of adult wistar rats especially at higher dose, was also said to have detrimental effects on the integrity of the testes of wistar rats, and also decrease the level of sperm count, but did not result into infertility (Buraimoh et al.,2012).The reproductive toxicology of aluminum in male mice has been studied and noticed that some histological changes, including necrosisofspermatocytes and spermatids in the testis of male mice treated with aluminum nitrate (Liobet et al., 1995). In addition, the same toxicity on mice testis after the effect of sodium fluoride and/or aluminum chloride has been reported (Memon and Chinoy 1998). Aluminum may alter and complicate the function of calcium and its biological effects leading to the sex hormone changes(Shahreki et al,.1999). The effects of administered $\mathrm{AlCl} 3$ on rats' testes was studied and observed that, decrease in body and testes weights and testosterone hormone. In addition, histological changes as damages within the seminiferous tubules and vascular degeneration of the germ cells and Sertoli cells cytoplasm(Mahran et al., 2011).(Krasovskii et al., 1979) studied the biological effects of lead and aluminium on rats and guinea pigs and observed that the lead and aluminium chloride caused gonad toxicity . (Mayyas et al., 2005) reported that histological changes in testicular sections of adult male mice after ingested aluminium chloride. And also, (Llobet et al., 1995) studied the reproductive toxicology of aluminium in male mice and observed that some histological changes, including necrosis of spermatocytes and spermatids in the testis of male mice treated with aluminium nitrate.Hence, this study was undertaken to examine the effect of different aluminum chloride concentrations on levels of FSH,LH and testosterone hormones and histological aspects of testis and epdidimus of rats.

\section{Martial and Methods:}

Experimental animals:The experiment was conducted at the animal house of the Veterinary Medicine, University of Basrah, where 32 males white laboratory rats (Rattus norvegicus) sexually mature (16 weeks age) and $250 \pm 50$ gm weighing, were used. The animals were accommodated in the same laboratory condition by keeping them in special cages for about 15 days. The experiment conditions were unified for all animals, where the room temperature was set between $20-25{ }^{\circ} \mathrm{C}$ by the use of air conditioner, and the light period was 12 hours daily, by the use of two fluorescent lamps, and the humidity rate was about $50 \%$. Food and water were provided daily (ad libitum).

Experimental Design:The animals were divided into Fourth groups, 8 for each one : control group was given distil water while the Aluminium exposed groups were given various concentrations of aluminium chloride as follows:

Group I was the Control

Group II received $25 \mathrm{mg} / \mathrm{Kg}$

Group III received $50 \mathrm{mg} / \mathrm{kg}$

Group IV received $100 \mathrm{mg} / \mathrm{kg}$

The route of administration was through oral and the duration of administration was 21 days.

\section{Experimental Procedure: \\ Hormonal Assay:}

The blood collected from each rat from the heart after deep inhalation of chloroform. Serum was obtained and stored at $-20 \stackrel{\circ}{\mathrm{c}}$ until ELISA hormonal assay was done. LH,FSH and Testosterone concentrations in the serum were quantified by commercial available kits (Human, Germany).

\section{Procedure of Tissue Processing:}

Brief the routine sequence of events is as follows (Luna , 1960):

1- Obtain the tissue

2- Fix for 24 hours or more in an appropriate fixative buffered formalin $10 \%$.

3- Dehydrate through ascending alcohol (increasingly higher concentration) alcohols overnight.

4- Replace alcohol (clear) with xylol or chloroform.

5- Infiltrate with paraffin.

6- Embed in a block of paraffin. 
7- Cut thin sections on the microtome ( $5 \mu \mathrm{m}$ - thick).

8- Mount the section on glass slides.

9- Remove (dissolve) the embedding medium by putting the slides on hot plate overnight.

10- Rehydrate the sections in descending alcohols.

11- Stain the section with an appropriate staining sequence, Heamatoxline and Eosin (H\&E).

Statistical analysis: In this study, ANOVA analysis and LSD test were used according to (SPSS version 18) program at the $(\mathrm{P} \leq 0.05)$ to find the means for all treatments (SPSS, 2011).

\section{Results:}

\section{The Effect of Aluminium Chloride on Some Hormones Concentration}

Table (1) The Effect of Aluminium Chloride onSome Hormones Concentrations

\begin{tabular}{|c|c|c|c|}
\hline \multicolumn{2}{|l|}{$(\mathrm{M} \pm \mathrm{SD})$} & \multicolumn{2}{|c|}{$(n=8)$} \\
\hline parameters & LH & FSH & Testosterone \\
\hline $\begin{array}{c}\text { Control } \\
\text { Distal water }\end{array}$ & $\begin{array}{c}3.700 \pm 0.465 \\
\quad \mathrm{a}\end{array}$ & $\begin{array}{c}4.325 \pm 0.523 \\
\mathrm{a}\end{array}$ & $\begin{array}{c}7.150 \pm 0.267 \\
a\end{array}$ \\
\hline $\begin{array}{l}\text { Group (1): Low dose } \\
\quad(25 \mathrm{mg} / \mathrm{kg} \mathrm{B.W}) \mathrm{g} \mathrm{Al} / \mathrm{cl} 2\end{array}$ & $\begin{array}{c}3.412 \pm 0.344 \\
\text { a }\end{array}$ & $\begin{array}{c}3.762 \pm 0.555 \\
\quad \mathrm{a}\end{array}$ & $\begin{array}{c}6.362 \pm 0.972 \\
\text { a }\end{array}$ \\
\hline $\begin{array}{l}\text { Group(2): Intermediate dose } \\
(\mathbf{5 0} \mathbf{~ m g / k g ~ B . W ) ~ g ~ A l / c l 2 ~}\end{array}$ & $\begin{array}{c}1.325 \pm 0.786 \\
\text { b }\end{array}$ & $\begin{array}{c}2.175 \pm 0.592 \\
\text { b }\end{array}$ & $\begin{array}{l}4.087 \pm 0.840 \\
\text { b }\end{array}$ \\
\hline $\begin{array}{l}\text { Group(3):High dose } \\
(100 \mathbf{~ m g ~} / \mathbf{k g ~ B . W}) \mathbf{g ~ A l / c l} 2\end{array}$ & $\begin{array}{c}0.612 \pm 0.322 \\
\text { b }\end{array}$ & $\begin{array}{c}1.587 \pm 0.720 \\
\text { b }\end{array}$ & $\begin{array}{c}2.937 \pm 0.665 \\
c\end{array}$ \\
\hline LSD & $\overline{0.89}$ & 1.04 & 1.27 \\
\hline
\end{tabular}

* The different letters refer to significant differences between groups at level of $(\mathrm{p} \leq 0.05)$.

The results show that there were no significant differences in LH, FSH and Testosterone

concentration between the male rats treated with the 25 $\mathrm{mg} / \mathrm{kg}$ B.W Aluminium chloride and control group .While a significant $(\mathrm{p} \leq 0.05)$ decrease in the LH, FSH and Testosterone concentrations were observed in the animals treated with 50 , and $100 \mathrm{mg} / \mathrm{kg}$ B.W Aluminium chloride respectively compared with control group and $25 \mathrm{mg} / \mathrm{kg} \mathrm{B.W}$ treated groups after 21 days of treatment.

\section{Histological Examination :}

The histological examination of the control testis shows normal spermatogenesis as shown in Figure (1). Whereas in the administrated group with $25 \mathrm{mg} / \mathrm{kg}$ B.W. aluminium chloride treated animals the histological examination showed testis of male rat having a slight suppression of spermatogenesis, Figure (2). Histological examination testis group that have been administrated $50 \mathrm{mg} / \mathrm{kg}$ B.W. aluminium chloride shows a moderate suppression of spermatogenesis, Figure (3). Whereas the testis group which treated with $100 \mathrm{mg} / \mathrm{kg}$ B.W shows a complete absence of spermatocytes, Figure (4). This study found that the histological changes of epididymis were increase parallelay as aluminium dose increase, in that epididmyis of animals group administered $25 \mathrm{mg} / \mathrm{kg}$ B.W. of aluminium chloride shows slight suppression of spermatocytes, Figure (6), where moderate suppression of spermatocytes has been observed in epididymis of $50 \mathrm{mg} / \mathrm{kg} \mathrm{B.W}$. of aluminium chloride treated group, Figure (7) and marked suppression of spermatocytes shown in $100 \mathrm{mg} / \mathrm{kg} \mathrm{B}$.W. of aluminium chloride treated group, Figure (8).

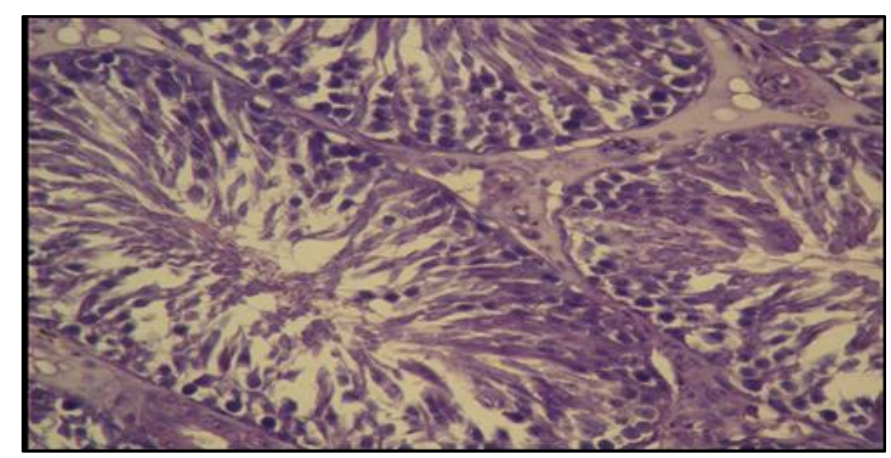

Figure (1) Testis of male rat treated with distal water show normal seminiferous tubules contain the variable stages of developing stain (H\&E).x500

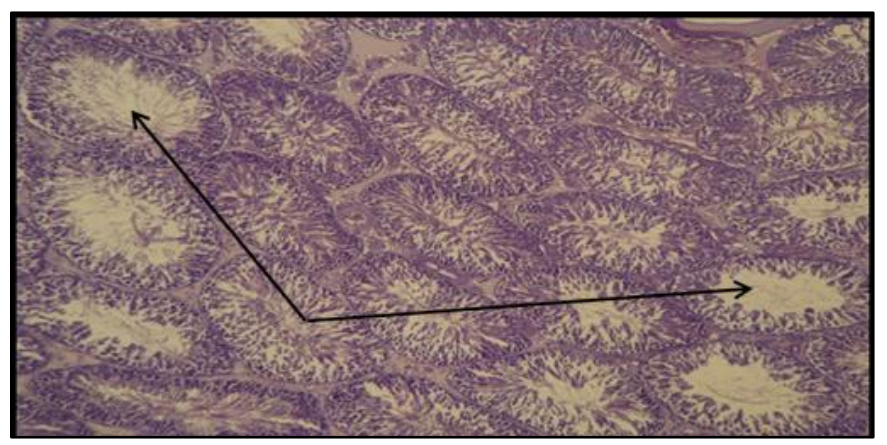

Figure (2) Testis of male rat treated with $25 \mathrm{mg} / \mathrm{kg}$ Alcl2 show slight suppression of spermatogenesis. Stain $(\mathrm{H} \& \mathrm{E}) . \mathrm{x} 125$ 


\section{J.Thi-Qar Sci.}

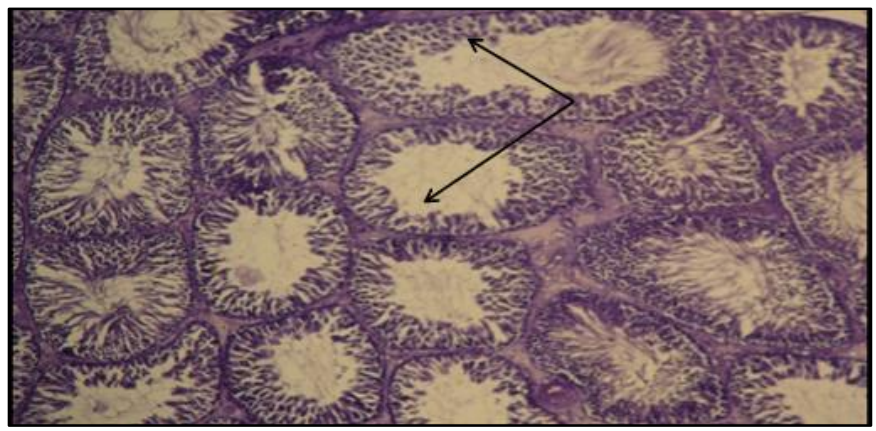

Figure (3) Testis of male rat treated with $50 \mathrm{mg} / \mathrm{kg}$ Alcl2 show moderate suppression of spermatogenesis. Stain (H\&E).x125

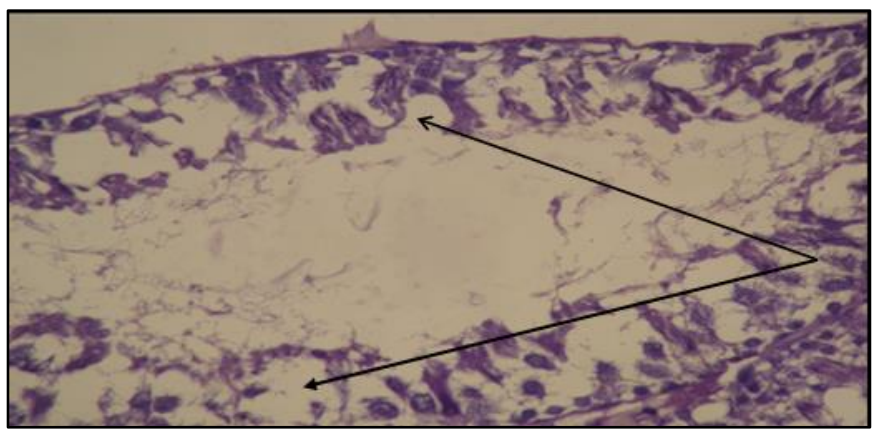

Figure (4) Testis of male rat treated with $100 \mathrm{mg} / \mathrm{kg}$ Alcl2 show complete absence of spermatocytes . Stain (H\&E).x500

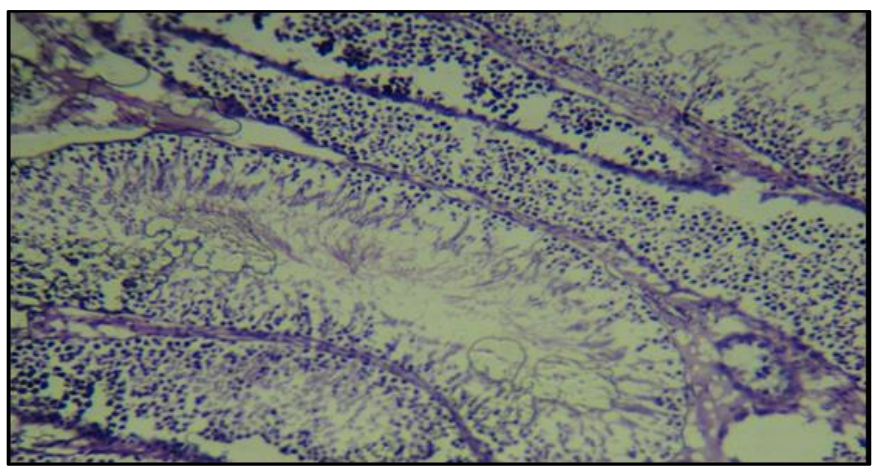

Figure (5) Epididymis of male rat treated with distal water show normal stages of developing . stain (H\&E).x125

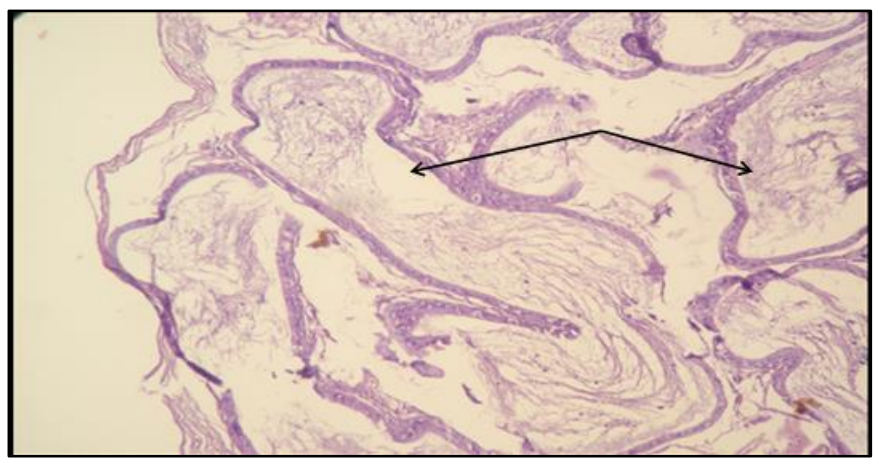

Figure (6) Epididymis of male rat treated with $25 \mathrm{mg} / \mathrm{kg}$ Alcl2 show slight suppression of spermatocytes. Stain (H\&E).x 125

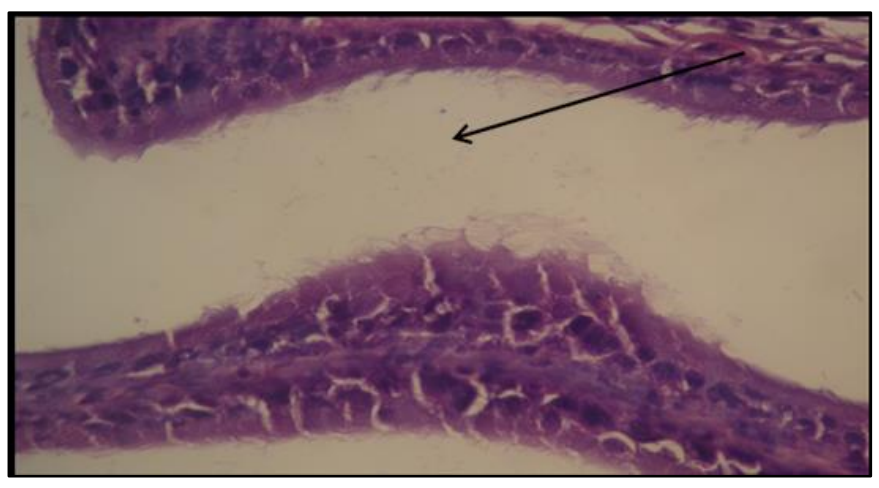

Figure (7) Epididymis of male rat treated with $50 \mathrm{mg} / \mathrm{kg}$ Alcl2 show moderate suppression of spermatocytes .Stain (H\&E).x500

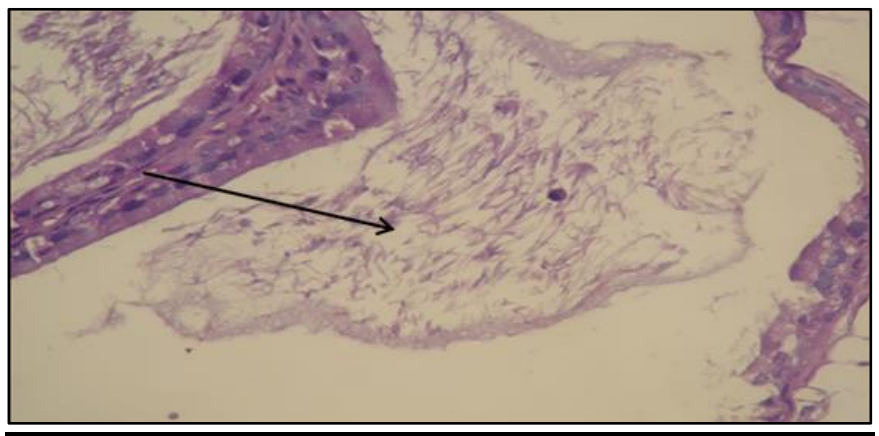

Figure (8) Epididymis of male rat treated with $100 \mathrm{mg} / \mathrm{kg}$ Alcl2 show marked suppression of spermatocytes .Stain (H\&E).x500

\section{Discussion:}

\section{The Effect of Aluminium Chloride on Some Hormones Concentration}

The results of the present study indicate that the treated rats with aluminium chloride in doses 25, 50 and $100 \mathrm{mg} / \mathrm{kg}$ daily for 21 days periods have shown a 
significant decrease $(\mathrm{P} \leq 0.05)$ in the serum LH , FSH and testosterone which are represented in tables (1), compared with the control group. Aluminium chloride can exert a significant adverse effect on reproductive performance in the animal model (Yousef et al.,2005). This effect can be exerted centrally, peripherally or both. Aluminium is a Voltage Sensitive Calcium Channels blocking (Yousef and Salama, 2009) and can affect neurotransmitter release (Jones and Kochian ,1997). These results were in line with the results reported by (Yousef, 2004) who showed that aluminium chloride was able to generate reactive oxygen species in rabbit's testes. Guo et al., (2005). demonstrated also that, exposure to aluminum lowered plasma and testicular testosterone levels in mice. Decrease in the LH release will lead to the reduction in the serum concentration of testosterone as it is shown in this study. Decrease in the level of testosterone will eventually be reflected on the peripheral sex organs functions including epididymis and testis (Shahraki, et al.,2008).

\section{Histological parameters :}

The histological examination of testis of the control shows the normal size and shape of the and testis other structures, as in Figure (1).When animals treated with $25 \mathrm{mg} / \mathrm{kg}$ B.W. aluminium chloride the histological examination shows slight suppression of spermatogenesis as in Figure $(2,3)$ and complete absence of spermatocytes, Figure(4).Many toxic metals damage testicular germinal epithelium (Abdel-Moneim et al., 2008). Our main findings in Al-treated mice were deformations of the Sertoli cells, epithelial sloughing, tubular atrophy, and abnormal germ cells. According to (Hess and Nakai,. 2000), sloughing of immature germ cells is caused by a disruption of microtubules and intermediate filaments of the Sertoli cells. Guo, et al. 2002 have reported that aluminium caused suggested that ACE activity had a role in oxidative damage of Al-induced testicular toxicity in mice, after intraperitoneally exposed to 0.13 or $35 \mathrm{mg}$. A $1 . / \mathrm{kg}$. body weight for a period of 14 days.Mayyas et al.,(2005) reported the same resulted after the mice treatment with aluminium chloride, and found that destruction of the seminiferous tubules with large necrotic areas and degenerative cells. These result agreed with (Guo, et al., 2002;Kattab , 2007;Ashraf and Abdel moneim, 2013). The examination of Epididymis of the control groupe shows the normal size and shape of the Epididymis and other structures, as in Figure (5). When animals treated with $25 \mathrm{mg} / \mathrm{kg} \mathrm{B}$.W. aluminium chloride the histological examination shows suppression of spermatocytes , as illustrated in Figure $(6,7,8)$.these result agreed with (Chinoy et al.,2005) they showed marked histological changes in the epididymis, decreased levels of protein and sialic acid the mechanism for $\mathrm{Al}$ which induced oxidative stress is lipid per oxidation. The mechanism for $\mathrm{Al}$ which induced oxidative stress is lipid peroxidation , Malondialdehyde (MDA) is a well known lipid peroxidation indicator and found to be increased in and epididymis after $\mathrm{Al}$ exposure (Yousef and Salama, 2009). Increase lipid peroxidation might be caused by interference with mineral metabolism/ distribution. The capacity of $\mathrm{Al}$ to displace other biological cations such as calcium, iron, zinc, copper and magnesium from their binding sites is a potential target for the adverse effects of $\mathrm{Al}$ (Yokel ,2009).

\section{Reference :}

Abbasali, K.M, Zhila, T. and Farshad, N.( 2005). Developmental Toxicity of aluminium from High Doses of $\mathrm{AlCl} 3$ in Mice. The Journal of Applied Research, 5: 575-579.

Abdel-Moneim, A.M.; Al-Rawi, M.M.; Abu El-Saad, A.M. and Sorour, J.M.(2008). Changes in oxidative stress, testicular enzymes, histological and ultrastructural characteristics of seminiferous epithelium and semen quality of rats after in vivo exposure to lead and/or cadmium. J Exp Zool India;11:341-52.

Ashraf M. Abdel MoneiM (2013). Effect of tarurine against histomorphological and ultrastrctural changes in the testis of mice exposed to Aluminium chloride Arh. Hig Rada Toksikol;64:405-414.

Buraimoh ,A.; Ojo, S.; Hambolu J and Adebisi,S.(2012). Aluminium Chloride Exposure Had No Effects on the Epididymis of Wistar Rats. American Medical Journal 3 (2): 210-219.

Chinoy, N.J.; Momin, R. ; Jhala, D. and Fluoride, D. (2005) . Aluminium induced toxicity in mice epididymis and its mitigation by vitamin C, Fluoride, 38 115-121.

Guo, C. ; C. Huang, Y. Chiou and HSU, G. ( 2002). Alteration of trace element distribution and testis A C E activity in mice with high peritoneal aluminium, J. B iol. T race. Elem. Res. , 86(2): 145-157.

Guo,C.; Lu,Y. and Hsu,G.S.W. (2005). The influence of aluminum exposure on male reproduction and offspring in mice. Environ. Toxicol. Pharmacol., 


\section{0:135-141.}

Hess, R.A. and Nakai, M.(2000). Histopathology of male reproductive system induced by the fungicide benomyl. Histol Histopathol 15:207-24.

Jones, D.L. and L.V. Kochian, (1997). Aluminum interaction with plasma membrane lipids and enzyme metal binding sites and its potential role in all cytotoxicity. FEBS Lett., 400: 51-57.

Khattab,F. K..(2007). Histological and Ultrastructural Studies on the Testis of Rat after Treatment with Aluminium Chloride. Australian Journal of B asic and Applied Sciences, 1(1): 63-72.

Koenig, M. L and Jope, R. S. (1987). Aluminum inhibits the fast phase of Voltage-Dependent Calcium influx in to synaptosome . J Neurochemistry ; 49: 316-320.

Krasovskii, G.L.; Vasukovich and Chariev, G. (1979). Experimental study of biological effects of lead and aluminium following oral administration. Environ. Health Perspect,30: 47-51.

Liobet, J.M.; Corbella, J.; Domingo. J.L.; Sirventand, J.J.and Colomina, M.T. (1995) Reproductive toxicology of aluminum in male mice. Fund. Applied Toxicol.; 25:45-51.

Llobet, J.M..; Domingo, J.L. and Gomez, M. et al ( 1987). Acute toxicity studies of aluminum compoundsantidotal efficacy of several chelating agents. Pharmacology and Toxicology. 60: 280-283.

Luna, L.G.(1960). Manual of histological staining method of the armed forced institute of pathology. Third ed. Mcgraw-Hill Book Company, London. Pp:1-47.

Mahran,A.A; Abdel-Rahman,A.H. and Abd ElMawla,A.M.(2011).Role of propolis in improving male rat fertility affected with aluminum chloride cytotoxicity. Spatula DD, 1(4): 189-198.

Mayyas, I. A.; Elbetieha, W. K.; hamasand, A. and Hamas, K. (2005). Evaluation of reproductive and fertility toxic potentials of aluminium chloride on adult male mice, J. of Anim. \& V etr. Adv. , 4(2 ): 224-233.

Memon, M.R. and Chinoy, N.J.( 1998). Effect of sodium fluoride and/oraluminum chloride treatments on some organs of male mice [abstract]. XVIth National Symposium on Reproductive Biology and Comparative Endocrinology; Jan 21-22; University of Kerala, Trivandrum, India

Mestaghanmi, H,: El-Amrani S, and Saile, R.( 2002). Effects of aluminium chloride administration during gestation in rat. Stal. ,27:73-81.

Naraynan , S .(2014). Comparative study of effect of aluminium chloride and aluminium hydroxide on serum biochemical parameters in wistar albino rats. Int J Pharm Bio Sci ; 5(1): 253 - 258.

Newairy, A .S, Salama, A. F, Hussien, H.M and Yousef, M.I. (2009). Propolis alleviate aluminium-induced lipid peroxidaion and biochemical parameters in male rats. Food Chem Toxicol. 47(6):1093-8.

Shahraki, M.; Palan Mony,E.; Zahedi , S.; Sarkaki, A and Shahraki,A,R.( 2008). Effects of Aluminium Chloride Injection in Lateral Ventricle on Serum Gonadothropines, Testosterone and Spermatogenesis in Rats. Journal of Medical Sciences, 8: 410-414.

Shahreki, M.R.; Sarkaki, A.R. and Zahedi, S.(1999). Effect of oral Aluminum intake on sex hormones of rat. Feyz Journal of Kashan University of Medical Sciences. 3, (1) : 78-86.

Shuchang, H.; Qiao, N. \& Piye, N. (2008). Protective effects of gastrodia elata on aluminium-chlorideinduced learning impairments and alterations of amino acid neurotransmitter release in adult rats. Restor Neurol Neurosci.;26(6):467-73.

Sinczuk-walczak , H.; Szymczak , M .; Razniewska ,G.; Matczak, A and Wieslaw , S.(2003). Effects of occupational exposed to aluminium on nervous system: clinical and eletroencephlographic finding. International Journal of Occupational Medicine and Environmental Health, 16(4): $301-310$.

SPSS. (2011). SPSS for windows for release 18.000 Standard version, USA.

Verstraeten, S.V., Aimo, L., Oteiza, P.I., (2008). Aluminium and lead: molecular mechanisms of brain toxicity.Archives of Toxicology. $82: 789-802$.

Wurtman, R. J. (1985). Alzheimer's disease. Sci Am .252 :62-66,72-74.

Yokel, R.A., (2000). The toxicology of aluminum in the brain: a review. Neurotoxicology 21(5), 13-828.

Yousef,M.I. (2004). Aluminum-induced changes in hemato-biochemical parameters, lipid peroxidation and enzyme activities of male rabbits: Protective role of ascorbic acid .Toxicology , 199: 47-57.

Yousef,M.I. and Salama, A.F.(2009). Propolis protection from reproductive toxicity caused by Aluminium chloride in male rats .Food and Chem.Toxilogy.47:1168-1175.

Yousef,M.I.; El-Morsy,A.M.A. and Hassan,M.S. (2005). Aluminium induced deterioration in reproductive performance and seminal plasma biochemistry of male rabbits: protective role of ascorbic acid. Toxicology, 215: 97-107. 